[Pre-publication version. Published version in Modern Theology 31/3 (July 2015), pp. 428-44]

\title{
On the Affective Salience of Doctrines
}

\author{
SIMEON ZAHL
}

In his classic study, The Nature of Doctrine, George Lindbeck articulates an account of Christian doctrinal statements as fundamentally 'regulative' in nature. In his view, the best way to understand 'church doctrines' is in terms of 'their use, not as expressive symbols or truth claims, but as communally authoritative rules of discourse, attitude, and action. ${ }^{1} \mathrm{~A}$ religion, Lindbeck tells us, is first and foremost 'a kind of cultural and/or linguistic framework or medium that shapes the entirety of life and thought,' and church doctrines make up a significant part of that cultural-linguistic framework. As Mike Higton explains, this means that 'to understand any [doctrinal] proposition one must attend to the weave of practice within which it is made', and 'attend[] to the way [religious truth claims] are involved in the whole shaping of communal and individual life.' 2

According to Lindbeck, there are several arenas in which this 'shaping' or 'regulation' occurs. First and foremost, doctrines help shape the form, content, and style of Christian discourse, both among Christians and between the church and the world. Second, doctrines inform and are informed by Christian 'action' broadly construed, encompassing both liturgical and pastoral practice as well as Christian ethical life in its many forms. And finally, and most importantly for the discussion that follows, Lindbeck argues repeatedly that, as a key part of the grammar of Christianity as cultural-linguistic framework, doctrines have a deeply shaping impact on individual and communal religious experience. Early on in the book, Lindbeck states quite bluntly that 'the linguistic-cultural model is part of an outlook that stresses the degree to which human experience is shaped, molded, and in a sense constituted by cultural and linguistic forms.' To 'become religious' is to learn not only how to act and think, but also how to 'feel... in conformity with a religious tradition.'

What Lindbeck seems to have particularly in mind in his discussions of experience is religious experience as 'feeling' or emotion. Arguing against what he calls an 'experientialexpressive' approach to Christian doctrine, Lindbeck claims that '[r]eligious experiences in the sense of feelings, sentiments, or emotions... result from... conceptual patterns[,] rather

\footnotetext{
${ }^{1}$ George A. Lindbeck, The Nature of Doctrine: Religion and Theology in a Postliberal Age (London:

Westminster John Knox Press, 1984), 18.

${ }^{2}$ Mike Higton, 'Reconstructing The Nature of Doctrine', Modern Theology 30/1 (2014), 10.

${ }^{3}$ Lindbeck, The Nature of Doctrine, 34-35. Emphasis added.

Simeon Zahl,

University of Oxford, Faculty of Theology and Religion, St John's College, St Giles, Oxford OX1 3JP, UK

Email: simeon.zahl@theology.ox.ac.uk
} 
than being their source. ${ }^{4}$ He continues: 'First come the objectivities of religion, its language, doctrines, liturgies, and modes of action, and it is through these that passions are shaped into various kinds of what is called religious experience. ${ }^{5}$ There are two points to be drawn from this: first, that the main form of religious experience for Lindbeck has to do with 'passions' and emotions, and second, that Lindbeck takes a strongly constructivist view of religious experience and emotion - in his view, experience does not exist prior to the cultural and linguistic structures through which it is articulated and interpreted, and, indeed, 'experienced'.

It is here, with these broad and general claims, that Lindbeck's discussion of religious experience and religious emotion ends. Setting aside for the moment the question of whether a strong constructivist view of affective religious experience like his is still viable today, a weak version of his constructivist claim is not particularly controversial. Religious doctrines, languages, liturgies, and modes of action clearly do have a shaping effect of some kind on religious experience, and, as we will see, there is a long history of theological awareness of this fact. At the same time, and here is a key point, Lindbeck does not give any further account in The Nature of Doctrine of how exactly this shaping and constructing of experience and emotion takes place in concrete instances and settings.

As a result not least of the influence of Lindbeck's model, it is not unusual today for theologians to talk about the vital role of Christian theology and practice in shaping our imaginations, in molding and reconstructing our desires, and in altering our emotional life. One influential example is James Smith's book, Desiring the Kingdom, which argues, in a Lindbeckian mode, that 'cultural practices', both secular and religious, are 'quasi-liturgies' that 'shape our imaginations' and 'effect an education of desire, a pedagogy of the heart'... 'in all sorts of precognitive ways.' ${ }^{6}$ Another recent example is Medi Ann Volpe's

Rethinking Christian Identity, which draws on Gregory of Nyssa to describe a vision of how 'doctrine orients the imagination', 'nourishes the soul', and 'enables the soul to evade the bondage of the passions'.

The question I am interested in exploring in this article, for which Lindbeck has no clear answer, and toward which theologians like Smith and Volpe have only begun to indicate the way forward, is: how does all this actually work more specifically, in particular concrete instances in human lives? For example, which kinds of emotion and experience are shaped by which doctrines and practices? Are some doctrines more oriented towards emotional

\footnotetext{
${ }^{4}$ Ibid., 39. Emphasis added.

5 Ibid., 39.

${ }^{6}$ James K.A. Smith, Desiring the Kingdom: Worship, Worldview, and Cultural Formation (Grand Rapids, MI: Baker Academic, 2009), 24-25.

${ }^{7}$ Medi Ann Volpe, Rethinking Christian Identity: Doctrine and Discipleship (Oxford: Wiley-Blackwell, 2013), 196.

${ }^{8}$ Ibid., 212. Likewise, 'The reshaping of desire is central to the formation of our Christ-likeness, and Gregory identifies two tools for reworking the heart: doctrine and ascetic practice' (224). Scripture, in Volpe's interpretation of Gregory, serves a similar and indeed overlapping function to doctrine (199). Although Volpe's discussion, like Smith's, at times relies on overly-generalized claims about doctrine's shaping effect on desire and imagination - e.g., the vague assertion that through texts 'the heart is molded... into a receptacle for divine love' (199) - she does go further than Smith in explicating the connection between doctrine and desire in at least two more concrete respects, namely, in relation to hope and to memory (189-96 and 207-217).
} 
impact or desire-shaping than others? And what are the different forms that such impact can take - can we, say, talk about certain doctrines being problematic because they tend to have problematic affective effects, and can we describe other doctrines as being affectively 'wise' because of how they help foster and regulate more positive, theologically legitimated emotions?

It seems to me that if theologians wish to speak of doctrines as having practical 'shaping' and 'regulative' effects on the human beings who constitute the church in the world - and broadly speaking, I think this is indeed a useful way to proceed - then the devil is very much in the details. For all the power and plausibility of Lindbeck's conceptualities, there is a danger in keeping analysis of how doctrines function on too general a level. At best, simply stating that cultural-linguistic frameworks significantly shape religious experience, or that doctrine and liturgy orient imagination and desire, risks banality as mere assertions of the obvious point that our contexts shape our lives. At worst, these sorts of claims allow one to make plausible-sounding assertions and arguments about doctrines that are in fact empirically falsifiable. For example, Lindbeck's starkly constructivist view of the relation between cultural-linguistic frameworks (in this case, doctrines) and emotion - ultimately a key feature of his project - must increasingly be viewed as simply empirically mistaken in light of contemporary psychological accounts of the relation between cognition and emotion in human beings. ${ }^{9}$

\footnotetext{
${ }^{9}$ Lindbeck is partially indebted to Wayne Proudfoot's influential work on religious experience and emotion (Lindbeck, 29, n. 31). Proudfoot's deeply constructivist position on religious emotion - most famously articulated in the book Religious Experience, but also appearing in an earlier article cited by Lindbeck (Wayne Proudfoot and Phillip Shaver, 'Attribution Theory and the Psychology of Religion', Journal for the Scientific Study of Religion 14/4 (1975), 317-30) - relies heavily on an experiment by psychologist Stanley Schachter in the 1960s which appeared to indicate that 'emotion is a combination of nonspecific physiological arousal and contextually determined cognitive labels' (Wayne Proudfoot, Religious Experience (Berkeley, CA: University of California Press, 1985), 100; see also 75-118, 218-21). Although Schachter's experiment was important in setting the direction of research into the cognitive components of emotion, his specific findings are no longer taken seriously by psychologists: according to Elaine Fox, 'in spite of several attempts, no study has been able to fully replicate the effects' of Schachter's key experiment, and his theory thus 'does not appear to be valid' (Elaine Fox, Emotion Science: Cognitive and Neuroscientific Approaches to Understanding Human Emotions (New York: Palgrave Macmillan, 2008), 150-51). In an important recent work, Ann Taves has attempted to 'recover and extend Proudfoot's efforts in light of more recent work in psychology', though she focuses on psychological research into meaning attribution rather than the psychology of emotion, which is our focus here. See Ann Taves, Religious Experience Reconsidered: A Building-Block Approach to the Study of Religion and Other Special Things (Princeton, NJ: Princeton University Press, 2009), 94, 88-140.

A further counterpoint to Lindbeck's stark social and cultural constructivism on emotion is the line of research associated with Paul Ekman and others into 'basic emotions' that are connected to particular facial expressions and have been shown to manifest to some degree across cultures (see e.g., the seminal article 'An Argument for Basic Emotions', Cognition and Emotion 6 (1992), 169-200; for a more recent and nuanced view, see David Matsumoto and Paul Ekman, 'Basic Emotions' in The Oxford Handbook to Emotion and the Affective Sciences, David Sander and Klaus R. Scherer (eds), (Oxford: Oxford University Press, 2009), 69-72). Although debate continues over the ultimate value of the term 'basic emotions', even the most 'constructivist' recent psychological accounts of affective processes reject the sort of simplistic social and cultural constructivism adopted by Lindbeck and Proudfoot, and emphasize instead the enormous complexity and variation that exists within the processes traditionally referred to as emotions (see especially James A. Russell, 'Emotion, core affect, and psychological construction', Cognition and Emotion 23/7 (2009), 1267, as well as Lisa Feldman Barrett, 'Variety is the spice of life: a psychological construction
} 
The question, then, is: how might we go about proceeding beyond the general and the banal in claims about the connections between doctrine on the one hand and religious experience, affectivity, and desire on the other? My proposal is to attend explicitly to what I will call 'the affective salience of doctrines'. 'Affective salience' is a term drawn from the discipline of psychology, where an object of our attention is understood to be 'affectively salient' to the degree that it evokes and brings to awareness particular bodily affective states. Biggs, Kreager, et al, define affective salience as the 'personal affective valence of a stimulus ... i.e., the positive, negative, or neutral feelings evoked in the observer' by a particular object of consciousness. ${ }^{10}$ An 'object of consciousness' can be many things, as will be shown below, but for now the key point is that it can certainly include a particular theological image, conceptuality, or doctrinal position, insofar as encounter with it elicits 'personal affective valence' in the form of particular feelings or emotions.

There are at least two broad ways in which theologians could go about analyzing the affective salience of doctrines. One way - which will not be my focus here - would be empirical, contextual, and highly specific. Taking this route, one could draw on methodologies from the social and cognitive sciences to attempt to measure various affective responses to, say, a sermon or lecture on a particular doctrinal theme or to the experience of the eucharist for people who hold particular doctrinal views of what that experience signifies. In other words, one could measure and test the actual affective effects - as opposed to the merely intended ones - of particular doctrines communicated in particular empirically analyzable contexts. To do this well would be a task for sociologists and psychologists of religion, and there would be a great deal to learn from such an approach. $^{11}$

A second way would be more historical and theological, and it is this approach that I wish to pursue in the remainder of this article. It builds on a particular, under-recognized strategy of argument that theologians have used through the centuries to buttress or augment exegetical, logical, and traditional arguments. What I have in mind is a species of pastoral or experiential argument by which the case is made that it is only through accepting a particular account of a doctrine, and allowing that account to shape our religious practice,

approach to understanding variability in emotion', Cognition and Emotion 23/7 (2009), 1284-1306; for a vigorous critique of Barrett and Russell on this issue, see Nico H. Fridja, 'Emotions, individual differences, and time course: reflections', Cognition and Emotion 23/7 (2009), 1449-59).

Also relevant is recent work in cognitive science showing the pre-linguistic, animal background to key affective processes. According to Jaak Panksepp, current work on evolution and brain architecture shows that 'primary-process affective experience emerged in brain evolution much earlier than cognitive processes that allow us to think and talk about our internal experiences' (Panksepp, 'Affective Consciousness' in Max Velmans and Susan Schneider (eds), The Blackwell Companion to Consciousness (Oxford: WileyBlackwell, 2006), 114; see also idem, 'Affective Consciousness: Core Emotional Feelings in Animals and Humans', Consciousness and Cognition 14/1 (2005), 30-80). For an overview of current arguments against a strong linguistic and cultural constructivist position on emotion and experience in relation to religion, see Jason Blum, 'The Science of Consciousness and Mystical Experience: An Argument for Radical Empiricism', Journal of the American Academy of Religion 82/1 (2014), 150-73.

${ }^{10}$ Adam T. Biggs, Ryan D. Kreager, et al., 'Semantic and Affective Salience: The Role of Meaning and Preference in Attentional Capture and Disengagement', Journal of Experimental Psychology: Human Perception and Performance 38/2 (2012), 538, 531-41.

${ }^{11}$ For a book advocating the value of this sort of work, see Ole Riis and Linda Woodhead, A Sociology of Religious Emotion (Oxford: Oxford University Press, 2010). 
that people will experience the right sort of emotional outcome in their piety and practice and avoid some problematic emotional outcome. We could describe this as argumentation based on the expected affective salience of particular doctrinal positions. As we will see, one of the great values of attention to this form of doctrinal analysis is that it allows not only for a new interpretive angle on particular historical debates, but also for constructive engagement with and - in a limited but valuable way - testing of certain kinds of doctrinal positions through the insights of contemporary psychology and social science.

There are many historical examples I could give to illustrate the strategy of appealing to the affective salience of doctrines. One notable appeal of this kind arises in the disagreement between John Calvin and the authors of the Decree on Justification at the Council of Trent on the issue of election and assurance. In his argument in favor of predestination in the Institutes, Calvin asserts from the start that the value of the doctrine is not least that through it we come to 'sincerely feel how much we are obliged to God'. He argues that the doctrine should bestow upon those who understand and believe it 'firmness and confidence' and 'free[dom] from all fear' By contrast, 'all those who do not know that they are God's own will be miserable through constant fear.' ${ }^{12}$ In other words, Calvin argues we should agree with him on election not just because of exegetical-theological arguments about a text like Romans 8:29-30, but because it is only through correct understanding of this doctrine that a certain kind of fear of God can be correctly managed and dealt with.

The authors of the Decree on Justification at the Council of Trent argue the opposite case, but they too do so in part on affective grounds. Critical of the 'vain and ungodly confidence' they consider protestant views of assurance to be seeking, they argue that it is in fact perfectly appropriate, in light of human weakness and the limits of human knowledge, for a Christian to experience a certain 'fear and apprehension concerning his own grace'. ${ }^{13}$

Overconfidence, not fear, is the affective sin to be avoided.

What matters for our purposes is that, despite their disagreement, both Calvin and the Tridentines are explicitly concerned in their arguments with the affective salience of the doctrine of predestination as they perceive it. That is, they are attentive to the felt, emotional effects they expect belief in the doctrine to have in human lives, both positively and negatively. Both are as it were 'Lindbeckians' here, at least in a weak sense: although they disagree deeply on the details, both view the significance of this doctrine as dependent not just on whether it is right or wrong but also on how it shapes Christian affective experience, how it teaches Christians to 'feel...in conformity with [their] religious tradition."

Another example of theological appeal to the affective salience of doctrines can be found in Augustine's Homilies on the First Epistle of John. In the Sixth Homily, Augustine argues

\footnotetext{
${ }^{12}$ John Calvin, Institutes of the Christian Religion, vol. 2 (Louisville: Westminster John Knox Press, 1960), 922 (Book 3, chapter 21, section 1).

13 'vana haec et ab omni pietate remota fiducia'; 'de sua gratia formidare et timere potest'. H.J. Schroeder (ed and trans), Canons and Decrees of the Council of Trent (London: B. Herder Book Co., 1960), 314 (Eng.: 35). Sixth Session, Chapter IX.

${ }^{14}$ See note 3 above.
} 
that a number of heretical groups ${ }^{15}$ who claim to affirm the doctrine of the Incarnation in fact deny it with their deeds, and these deeds (what he has in mind are their specific actions causing church division) are in turn a reflection of their affections. In Augustine's view, to believe rightly in the Incarnation is to be filled with the affection of love:

[Christ] came in the flesh, therefore, in order to die for us. But how did he die for us? 'Greater charity than this no one has, than to lay down his life for his friends' (Jn 15:13). It was charity, then, that led him to the flesh. Whoever doesn't have charity, therefore, denies that Christ has come in the flesh... You [heretics] don't have charity because... you cause divisions in unity... How do you not deny that Christ has come in the flesh, you who break up the Church of God that he gathered together? ${ }^{16}$

As in the sixteenth-century debate over predestination, what we find here is an explicit rhetorical concern with the affective consequences of a particular doctrinal position, in this case to do with the Incarnation. According to Augustine, a correct view of Christ's 'coming in the flesh' will result in a love for God and neighbor that will promote and resource the unity of the Church, and an incorrect view will accomplish the reverse. Indeed, for him, affectively sourced behavior here is more trustworthy than mere verbal consent to a doctrine, because, regardless of what a person says verbally, where the affection of love is not present, the Incarnation is denied: 'The Spirit of God, then, is he who says that Jesus has come in the flesh, who says it... not with words but by loving., 17

A third historical example of appeal to the affective salience of doctrines can be found in Gregory of Nyssa's discussion of the Creator-creature distinction in the Catechetical Orations. As Medi Ann Volpe has shown - in an excellent recent instance of the sort of attentiveness to affective salience I am advocating here - Gregory's argument is that Christians should adhere to the distinction between Creator and creature not merely because as a doctrine it is 'correct', but because of the affective consequences of the doctrine for the 'creation and sustenance of [properly Christian] hope' and the 'reordering of desire'. ${ }^{18}$ In Gregory's words,

\footnotetext{
15 'Arians', 'Eunomians', 'Macedonians', 'Cataphrygians', and 'Novatians'. Augustine, Homilies on the First Epistle of John, Daneil E. Doyle and Thomas Martin (eds), Boniface Ramsey (trans), The Works of Saint Augustine I/14 (New York: New City Press, 2008), 100-101.

${ }^{16}$ Ibid., 102-103. Emphasis added.

${ }^{17}$ Ibid., 102. Although the meaning of 'charity' for Augustine in these sermons is complex - what he has in mind is as much an ethic and disposition in relation to neighbor and world as it is a simple emotion - it is a complexity that clearly includes a deep sense of charity's affective character. This is evident on 135-38 and 154, where Augustine explicates the meaning of charity in terms of a direct affective counterpoint to fear and anger. For more on this argument in Augustine, see Robert Dodaro, "Omnes haeretici negant Christum in carne uenisse” (Aug., serm. 183.9.13): Augustine on the Incarnation as Criterion for Orthodoxy', Augustinian Studies 38/1 (2007), 163-74. I am grateful to Natalie Carnes for drawing my attention to this example.

${ }^{18}$ Volpe, Rethinking Christian Identity, 189-96. As has been indicated, there are important commonalities between the larger vision of Volpe's book and what is being argued for in this article. For a related argument demonstrating ways in which doctrine can shape and order sensory experience (rather than just affective
} 
[If the catechumen] sees a created nature in the Trinity and is baptized into that... If... man is a created being and he thinks of the Spirit and the only-begotten God as similarly created, he would be foolish to hope for a change for the better when he is only reverting to his own nature. ${ }^{19}$

As Volpe explains, the significance of this for Gregory is that the salvific hope embedded in Christian baptism is not properly hope if its object is merely some vastly powerful creature, for then it has no enduring and reliable ground, and there can be no qualitative 'change for the better'. Right understanding of the Creator-creature distinction is important not simply because of its truth but also because it alone, in Gregory's view, will result in the affective outcome of rightly ordered hope.

These first three examples demonstrate the existence of the phenomenon of appeals to the affective salience of doctrines in major debates in the history of theology. They also indicate that the contours of such debates, including their specific doctrinal and confessional outcomes, are not adequately understood either historically or theologically unless these arguments about affective salience are taken into account. Attention to this aspect of these debates makes explicit the fact that doctrinal disputes in the history of theology are rarely purely exegetical, logical, or traditional, but often relate to a whole vision of what it is to be a Christian person in the world, and take for granted that one cannot make a wise decision about whether to support a doctrine without taking its the full practical impact and affective shape into account. But is there a constructive as well as historical value to attending to the affective salience of doctrines? How might this sort of theological approach help us in relation to contemporary theological debates?

In the second half of this article, a fourth, extended example will answer this question in relation to one specific ongoing discussion in contemporary theology: the recent wave of criticism directed at 'forensic' soteriologies and the corresponding turn across a variety of traditions toward soteriologies of 'participation' and theosis. ${ }^{20}$ An increasingly common critique of traditional protestant forensic soteriologies has to do with their affective salience: it is argued, on grounds that will be explored in a moment, that such doctrines are inherently 'cold', rationalistic, and disembodied. By comparing such critiques to the first and most influential articulation of 'forensic justification' in protestant theology - the account developed by Philipp Melanchthon in the 1531 Apology of the Augsburg Confession - and then assessing Melanchthon's account of the affective salience of the doctrine in light of contemporary insights from the psychology and philosophy of emotion, this well-known critique will be found surprisingly wanting. ${ }^{21}$

experience), see Mark R. Wynn, Renewing the Senses: A Study of the Philosophy and Theology of the Spiritual Life (Oxford: Oxford University Press, 2013), especially Chapter 5.

${ }^{19}$ Gregory of Nyssa, 'Catechetical Oration' in Edward R. Hardy (ed), Christology of the Later Fathers, Cyril Richardson (trans), Library of Christian Classics (Philadelphia, PA: Westminster Press, 1954), 322, 268-325 (or. catech. 39), quoted in Volpe, Rethinking Christian Identity, 190.

${ }^{20}$ See Simeon Zahl, 'Atonement' in Nicholas Adams, George Pattison, and Graham Ward (eds), The Oxford Handbook of Theology and Modern European Thought (Oxford: Oxford University Press, 2013), 651.

${ }^{21}$ For a full account of the origins of the forensic model of justification in Melanchthon, see Alister E. McGrath, Iustitia Dei: A History of the Christian Doctrine of Justification, third edn. (Cambridge:

Cambridge University Press, 2005), 235-41. 
Forensic justification, also known as the 'courtroom' metaphor in atonement theology, has long been a prominent feature of classical protestant views of salvation. Here is Melanchthon's famous description in the Apology:

The second qualification for a propitiator is this: his merits must be authorized to make satisfaction for others who are given these merits by divine imputation [imputatione divina] in order that through them, just as though [tamquam] they were their own merits, they may be reckoned [reputentur] righteous. It is as when a person pays a debt for friends, the debtors are freed by the merit of the other, as though it were by their own. Thus, Christ's merits are given to us so that we might be reckoned [reputemur] righteous by our trust in the merits of Christ when we believe in him, as though [tamquam] we had merits of our own. ${ }^{22}$

At the centre of this soteriological approach is the concept of 'imputation' or 'reckoning': Christ's righteousness is 'imputed' or 'reckoned' to the believer, through faith, such that when God looks at her He now sees Christ's perfection rather than the sinner's imperfection, and, in the classic legal analogy, on this basis 'acquits' her of the damnation she would otherwise deserve. This approach is traditionally contrasted with the broadly Thomist position that the formal cause of justification is God's righteousness 'infused' within the baptized believer as the habit of charity, such that, in the Council of Trent's classic formulation - which explicitly invokes and then rejects the 'reckoning' and 'imputation' language from Melanchthon's Apology - 'we are not merely reputed [non modo reputamur] but are truly called and are righteous, receiving righteousness [justitia] within us. ${ }^{, 23}$ For Melanchthon, by contrast, imputation means that we are treated 'as though' [tamquam] we were righteous, and salvation is thus at its core formally disconnected from our actually being righteous in ourselves in any sense.

The most prominent line of critique of this approach is that it is thought to offer no satisfying way of connecting what is happening objectively coram deo, before God, with subjective human experience in the world. The connection, such as it is, is an abstract, intellectual one only - it is a conceptual game, a kind of shifting of counters in the sky, rather than a lived and livable reality. 'Forensic' salvation, it is argued, is achieved through the exploitation of a legal loophole rather than through an actual participatory and transformative salvific engagement with the human creature. As a 'reckoning' rather than an infusion or transformation, the doctrine is thus accused of being a 'legal fiction'.

\footnotetext{
${ }^{22}$ Apology of the Augsburg Confession, Article XXI, paragraph 19. Latin: Die Bekenntnisschriften der evangelisch-lutherischen Kirche, sixth edn. (Göttingen: Vandenhoeck \& Ruprecht, 1967), 320; Eng: Robert Kolb and Timothy J. Wengert (eds), The Book of Concord, Charles Arand, Eric Gritsch, et al (trans) (Minneapolis, MN: Fortress Press, 2000), 240. The language of 'authorization to make satisfaction' and of 'reckoning of Christ's merits' to us 'as though we had merits of our own' implies the activity of a judge in a courtroom, and relies on Erasmus' gloss, in the notes to his 1516 critical edition of the New Testament, on the Pauline term logizomai in Romans 4:4 in terms of a procedure for the remission of debt in Roman law courts. See Erasmus, Novum Instrumentum Omne, first edn. (Basel: Johann Froben, 1516), 429; and McGrath, Iustitia Dei, 239-40.

23 'Demum unica formalis causa est justitia Dei, non qua ipse justus est, sed qua nos justos facit... et non modo reputamur, sed vere justi nominamur et sumus, justitiam in nobis recipientes', Council of Trent, Session Six, Chapter VII (Schroeder, Canons and Decrees of the Council of Trent, 312).
} 
The most robust and sophisticated version of this long-standing critique traces the problem to specific metaphysical developments in medieval scholastic theology - namely, the univocal and nominalist legacies of Scotus and Ockham. According to Catherine Pickstock, Duns Scotus' concept of metaphysical univocity allows and ultimately necessitates a position in which 'the space [of connection between God and humanity] is philosophically pre-determined as a space of facts or empirical propositions. ${ }^{24}$ Building on this analysis, and observing rightly that Luther himself was deeply shaped by the metaphysics of the via moderna, ${ }^{25}$ John Milbank connects Scotist as well as Ockhamist traditions with the development of protestant theologies of salvation, arguing that Lutheran and Calvinist theologies of justification, insofar as they include significant forensic components, presuppose these rationalistic and anti-participatory scholastic metaphysical developments and are a natural consequence of them. ${ }^{26}$ In Milbank's view, imputation-based soteriologies, dependent as they are on a 'nominalist univocal metaphysics' not only make a 'real, inward reworking of our nature ${ }^{, 27}$ soteriologically unnecessary, they actually render any claim to such inner change metaphysically incoherent. Salvation becomes 'the pathetic gesture of "faith", a purely intellectual assent to 'a neat set of propositions about [Christ's] saving significance', ${ }^{28}$ and in this 'displace[s] the centrality of love in favor of themes of trust and hope'. ${ }^{29}$ Indeed, this 'extrinsicist and judicial concept of grace' - which, in Milbank's account, Protestants share with later Counter-Reformation thinkers like Suarez - 'was often deemed... to make no essential experiential difference to the human subject. ${ }^{30}$

\footnotetext{
${ }^{24}$ Catherine Pickstock, 'Duns Scotus: His Historical and Contemporary Significance', Modern Theology 21/4 (2005), 554, 553-56.

${ }^{25}$ The relationship between Luther, nominalism, and the origins of the theology of justification by faith is enormously complex, and was a topic of intense interest in Luther studies in the second half of the twentieth century. See especially Heiko Oberman, 'Headwaters of the Reformation: Initia Lutheri - Initia Reformationis' in idem (ed), Luther and the Dawn of the Modern Era (Leiden: E.J. Brill, 1974), 40-88; Graham White, Luther as Nominalist: A Study of the Logical Methods Used in Martin Luther's Disputations in Light of the Medieval Background (Helsinki: Luther-Agricola Society, 1994); and McGrath, Iustitia Dei, 176-86, 210-35. For the purposes of this essay, Milbank's broad reading of the roots of 'extrinsicist and judicial concept[s] of grace' (John Milbank, Beyond Secular Order: The Representation of Being and the Representation of the People (Oxford: Wiley-Blackwell, 2013), 226) in terms of nominalism and univocity, though historically-speaking overly simple, is not being disputed; what is at issue instead is his reading of the affective and experiential consequences of such concepts.

${ }^{26}$ Milbank's main discussions of protestant forensic and judicial soteriologies can be found in Beyond Secular Order, 62-64, 79-80, 86, 225-26; idem, 'Knowledge: The theological critique of philosophy in Hamann and Jacobi' in John Milbank, Catherine Pickstock, and Graham Ward (eds), Radical Orthodoxy: A New Theology, (London: Routledge 1999), 23-24; idem, 'Alternative Protestantism: Radical Orthodoxy and the Reformed Tradition' in James K.A. Smith and James H. Olthuis (eds), Radical Orthodoxy and the Reformed Tradition (Grand Rapids, MI: Baker Academic, 2005), 27-33; and idem, Being Reconciled: Ontology and Pardon (London: Routledge, 2003), 110-11, 223. For recent critiques of forensic justification along similar lines, see Hans Boersma, Heavenly Participation: The Weaving of a Sacramental Tapestry (Grand Rapids, MI: Wm. B. Eerdmans Publishing Company, 2011), 89-95; and, from a pentecostal perspective, Frank Macchia, Justified in the Spirit: Creation, Redemption, and the Triune God (Grand Rapids MI: Wm. B. Eerdmans Publishing Company, 2010), 38-48. Milbank's genealogical critique of forensicism is the most sophisticated, but my argument in what follows applies equally to any broad critique of judicial soteriologies as necessarily a 'cold' or abstract 'legal fiction'.

${ }^{27}$ Milbank, Beyond Secular Order, 79-80; see also 86.

${ }^{28}$ Ibid., 79-80.

${ }^{29}$ Milbank, 'Alternative Protestantism', 32-33.

${ }^{30}$ Milbank, Beyond Secular Order, 226.
} 
On the basis in significant part of this narrative, which has become highly influential in contemporary theology, there has been an increasing turn amongst protestant theologians in recent decades away from the more traditional forensic framework and towards the recovery of categories like participation, theosis, and union with Christ instead. ${ }^{31}$ Forensic justification has come to be seen as a 'cold, abstract, logical, and judicial' doctrine that in contemporary theology is far less plausible than alternative accounts of atonement, especially those involving the categories of participation or theosis. ${ }^{32}$

On the face of it, this line of critique is quite compelling, as it seems to make good sense of the fact that classical protestant theologies of forensic justification are indeed overwhelmingly concerned with the exclusion from soteriology of any inner requirement of righteousness, and indeed of any inner change that would be formally necessary to salvation. Although from the start theologians who held to a forensic view of justification usually took great pains to emphasize some form of inner renewal or 'fruit' consequent to justification or simultaneous with it - usually called sanctification - they took equal pains to separate that renewal formally from salvation itself. ${ }^{33}$ Milbank is aware of this strategy but

\footnotetext{
${ }^{31}$ Paul Fiddes has observed that, by the early twenty-first century, 'It is no longer true, if it ever was, that western theology is only interested in a forensic view of salvation, or the acquittal of human beings in a divine law court', and soteriologies of participation and theosis have now come to hold 'a central place in all modern systematic theology' (Paul Fiddes, 'Salvation' in John Webster, Kathryn Tanner, and Iain Torrance (eds), The Oxford Handbook of Systematic Theology (Oxford: Oxford University Press, 2007), 176). This trend is especially evident in the many recent efforts to retrieve themes of divinization in Luther and union with Christ in Calvin. For the former, associated with the 'Finnish interpretation' of Luther, see especially Carl E. Braaten and Robert Jenson (eds), Union with Christ: The New Finnish Interpretation of Luther (Grand Rapids, MI: Wm. B. Eerdmans Publishing Company, 1998) and Tuomo Mannermaa, Christ Present in Faith: Luther's View of Justification (Minneapolis, MN: Augsburg Fortress, 2005). For participation and union with Christ in Calvin, see especially Todd Billings, Calvin, Participation, and the Gift: The Activity of Believers in Union with Christ (Oxford: Oxford University Press, 2008) and Julie Canlis, Calvin's Ladder: A Spiritual Theology of Ascent and Ascension (Grand Rapids, MI: Wm. B. Eerdmans Publishing Company, 2010).

32 Thomas Coates, 'Calvin's Doctrine of Justification', Concordia Theological Monthly 34/6 (1963), 333-34. Another commentator laments that 'In the present culture, to say that justification is primarily forensic is the rhetorical equivalent of saying that one teaches an implausible, cold, impersonal, and even arbitrary doctrine of justification' (R. Scott Clark 'Iustitia Imputata Christi: Alien or Proper to Luther's Doctrine of Justification?' Concordia Theological Quarterly 70/3-4 (2006), 272).

${ }^{33}$ See e.g., the Solid Declaration of the Formula of Concord [1577]: 'although renewal and sanctification are a blessing of our mediator Christ and a work of the Holy Spirit, they do not belong in the article or in the treatment of justification before God, but rather result from it' (Article III, paragraph 28); 'in the justification of the sinner before God, faith relies neither on contrition nor on love or other virtues, but only on Christ and (in him) on his perfect obedience, with which he fulfilled the law for us and which is reckoned [imputatur] to believers as righteousness' (Article III, paragraph 31). Kolb and Wengert, The Book of Concord, 566-67.
}

For a recent discussion of these issues in Luther, with bibliography, see Mark Mattes, 'Luther on Justification as Forensic and Effective' in Robert Kolb, Irene Dingel, and L'ubomir Batka (eds), The Oxford Handbook of Martin Luther's Theology (Oxford: Oxford University Press, 2014), 264-73. The theological relationship between justification by faith and sanctification in protestant thought, including the perennial Lutheran debate over whether such a distinction is even useful, is an enormous and complex topic, and has been the subject of intense debate from the start of the Reformation to the present. In the first generation of the Reformation alone there are several major phases in the discussion. For example, Luther's efforts to answer the question in On the Freedom of a Christian (1520) and Against Latomus (1521) are a very different beast from Melanchthon and Calvin's responses to the Osiandrian controversy in the 1540s and 1550s, and the second generation Lutheran Formula of Concord (1577) has to resort to special pleading to 
is highly skeptical: 'Supposedly the Protestant elect will be charitable, and yet if they happen not to be, this does not really seem to matter all that much. ${ }^{34}$ A true affection and habitus of love in the Christian believer is not just unlikely but finally precluded in his account of the forensic model: in developing an 'extrinsicist and judicial' theology of justification, 'the Magisterial Reformers ... compromised love as the heart of Christianity, replacing it with a loveless trust in an inscrutable deity'. The human relationship with God thus becomes disembodied and disinterested, a 'blind calculus'. 35

At work in this account is an implied claim about the affective salience of particular metaphysical positions, especially when applied to soteriology. The language in both Pickstock and Milbank about a reduction of soteriological realities to sheer facts and propositions, at the expense of experiential impact and inner transformation, includes within it a view that propositions on their own are insufficient motors of human affective transformation and response. In this sense there is particular account of the relation between emotion and the rest of cognition at work here: namely, the broad view that conceptual doctrinal positions on their own, divorced from a broader Thomist analogical metaphysics, are fundamentally disconnected from, or at least insufficiently connected to, embodied affective response.

That question that now arises is: how well does Milbank's account fit with Melanchthon's own account of the affective salience of forensic justification? Reading the article on justification in Melanchthon's Apology - and this extended confessional discussion is probably the most influential single text on justification in the first generation of the Reformation - we soon discover that far and away the leading set of images and descriptions in Melanchthon's account of justification are not so much forensic as affective. The over-riding image of salvation in the Apology, which appears on nearly every page in a fifty-page discussion, is not in fact the mechanism of forgiveness of sins through a transfer of Christ's merits - though, as we have seen, that too is present, with great consequences for later protestant theology - but that of a 'terrified heart' or 'terrified conscience' that seeks 'consolation' and 'peace'. ${ }^{36}$ And again and again where we might expect Melanchthon to speak of the consequences of justification in the objective, judicial terms of restored communion with God in eternity - i.e. in non-participatory, 'rationalistic', propositional terms - what we get instead are affective descriptions of the 'peace', 'love', and 'joy' which 'fill hearts', motivate righteous behavior, and cast out 'fear'. In justification, says

square Melanchthon's account of 'regeneration' in the Apology with the view of the Concordists on justification (see Solid Declaration, Article III, paragraphs 18-22, in Kolb and Wengert, The Book of Concord, 565-66) - and this is not yet to mention the long history of Reformed discussions of the themes. A full account of these developments lies far beyond the scope of this investigation, which limits its interest to the psychological plausibility of one particular contemporary critique (that of John Milbank) in relation to the specifically affective emphasis of one major early Reformation statement on the subject (Melanchthon's discussion in the 1531 Apology).

${ }_{34}^{34}$ Milbank, Beyond Secular Order, 225. Emphasis original.

${ }^{35}$ Ibid., 63-65.

${ }^{36}$ In addition to the references in the main text below, see e.g., Melanchthon, Apology of the Augsburg Confession, 124 ('terrors of conscience', 'frightened consciences'); 126 (' $\ldots$ in terrors, faith consoles and uplifts hearts... that we might then be able... to love God, truly to fear God...'); 129 ('terrified hearts'); 135 ('consolation' against 'terrors'); 136 (justification by faith leads to 'tranquil and joyful consciences before God'); 146 ('only that which brings peace to the conscience justifies before God'); and so on throughout Article IV. 
Melanchthon, 'we are not talking about an idle knowledge, such as is also to be found in the devils, but about a faith that resists the terrors of conscience and which uplifts and consoles terrified hearts. ${ }^{37}$ Indeed, 'We insist that faith justifies and regenerates inasmuch [dum] as it free us from our terrors and produces peace, joy, and new life in our hearts. ${ }^{38}$

In fact, faith cannot come into existence at all for Melanchthon outside the context of this existential, affective situation of anxiety before God: 'faith ... is conceived in the terrors of the conscience that experiences the wrath of God against our sin and seeks forgiveness of sins and deliverance from sin. ${ }^{39}$ In Melanchthon's view, any discussion of Christian salvation must begin with a particular set of what could be called 'affective predicates': in his account, all human beings, as soon as they begin to reflect on their nature and their relation to God, live with a kind of existential guilt and terror of judgment. ${ }^{40} \mathrm{He}$ explains this situation in detail in the section of the Apology on 'Repentance', quoting a series of Bible verses:

Scripture also speaks about these terrors as in ... Psalm 6: 'Be gracious to me, O Lord, for I am languishing; O Lord, heal me, for my bones are shaking with terror. My soul also is struck with terror, while you, $\mathrm{O}$ Lord - how long?' ... In these terrors the conscience experiences the wrath of God against sin, something unknown to those who walk around in carnal security ... [The conscience] flees the horrible wrath of God because human nature cannot withstand it unless sustained by the Word of God ... [H] ow will anyone love God in the midst of such real terrors when they experience the horrible and indescribable wrath of God? What else do they [the Roman Catholics] teach than despair, when in the midst of such terrors they present only the law? ${ }^{41}$

In light of these affective predicates of fear, guilt, and sorrow before God, the significance of a specifically forensic view for Melanchthon is that it alone can convincingly relieve that terror and provide peace and joy for the troubled human soul. As he puts it, 'the position we defend ... brings the surest consolation to godly consciences' ${ }^{42}$ There is no question that for Melanchthon the key to understanding forensic justification lies above all in understanding the powerful affective salience he perceives it to have for fearful human beings with troubled consciences. ${ }^{43}$

\footnotetext{
${ }^{37}$ Melanchthon, Apology of the Augsburg Confession, 158.

${ }^{38}$ Ibid., 197. See also 137 ('faith... produces peace, joy, and eternal life in the heart'); 140 ('Therefore after we have been justified and reborn by faith, we begin to fear and love God ... [and] to love our neighbor'); 165 ('Love necessarily follows regeneration' despite the fact that 'even after our renewal we are regarded as righteous on account of Christ').

${ }^{39}$ Ibid., 142.

${ }^{40}$ See especially 151 ('in genuine terror ... they end up in despair');158 ('the terrors of sin and death'); 193 ('the anxious heart'; 'anxieties, and the terrors of sin and death); and 195 (the sentence of the law 'is perceived only in the midst of genuine sorrows and terrors').

${ }^{41}$ Ibid., 192.

42 Ibid., 173

${ }^{43}$ On Melanchthon's affective theology, of which a snapshot has been given here, the scholarly literature is surprisingly sparse. See Karl Heinz zür Mühlen, 'Die Affektenlehre im Spätmittelalter und in der Reformationszeit' in Reformatorisches Profil: Studien zum Weg Martin Luthers und der Reformation,
} 
Clearly Melanchthon himself does not view the forensic model as cold, disembodied, and rationalistic at the expense of subjective personal engagement - quite the reverse in fact. What we are to make of this? Is Melanchthon simply mistaken here? Has he just not yet recognized that his conceptualities are not as successful as he thinks they are at holding together the objective legal mechanism we saw at the outset with its subjective, affective effects, and that in fact, as Milbank argues, the presence or otherwise of these embodied emotional effects ultimately 'does not appear to matter all that much'? ${ }^{44}$ Are Melanchthon's descriptions of the consolation of the terrified heart through forensic justification an exercise in wishful thinking, when in practice, due to its problematic metaphysical substructure, the actual result of such a soteriology is bound to be nothing more than 'loveless trust', a 'blind calculus' which is 'ineffective, 45 and makes little 'essential experiential difference to the human subject'?

In posing the question in this way, we are now in a position to test the plausibility of Melanchthon's account of the affective salience of forensic justification in relation to contemporary empirical understandings of emotion and its relation to the rest of cognition, specifically the relation between 'cognitive objects' and the elicitation of emotion. There is wide agreement today among psychologists and empirically engaged philosophers of emotion that emotions are helpfully understood to differ from mood states above all insofar as they 'involve cognitive appraisal as a defining feature', ${ }^{46}$ and thus possess an inherent 'intentionality'. ${ }^{47}$ Unlike either moods or the continuous affective hum of human experience

Johannes Brosseder (ed) (Göttingen: Vandenhoeck und Ruprecht, 1995), 101-22; idem, 'Melanchthons Auffassung vom Affekt in den Loci communes von 1521' in Michael Bayer, Günther Wartenberg, and Hans-Peter Hasse (eds), Humanismus und Wittenberger Reformation. Festgabe anlässlich des 500. Geburtstages des Praeceptor Germaniae Philipp Melanchthon am 16. Februar 1997 (Leipzig: Evangelische Verlagsanstalt, 1996), 327-336; Bernd Wannenwetsch, 'Affekt und Gebot. Zur ethischen Bedeutung der Leidenschaften im Licht der Theologie Luthers und Melanchthons' in Johann Anselm Steiger (ed) Passion, Affekt und Leidenschaft in der Frühen Neuzeit, vol. 1 (Wiesbaden: Harrassowitz Verlag, 2005), 203-15; idem, "Caritas Fide Formata. "Herz und Affekte" als Schlüssel zu "Glaube und Liebe"' in Kerygma und Dogma, 45 (2000), 205-224, as well as the extended discussion of Melanchthon's early affective theology in Wilhelm Maurer, Der junge Melanchthon zwischen Humanismus und Reformation, Studienausgabe, vol. 1 (Göttingen: Vandenhoeck \& Ruprecht, 1967). On the historical background and circumstances of the Apology, see Gunther Wenz, Theologie der Bekenntnisschriften der evangelisch-lutherischen Kirche, 2 vols. (Berlin: Walter de Gruyter, 1996-1997), vol. 1, 486-98; on the theology of justification in the Apology in relation to the other Lutheran confessional documents, see ibid., vol. II, 59-235.

${ }^{44}$ Milbank, Beyond Secular Order, 225.

${ }^{45}$ Milbank, 'Alternative Protestantism', 32-33.

${ }^{46}$ Panteleimon Ekkekasis, The Measurement of Affect, Mood, and Emotion: A Guide for Health-Behavioral Research (Cambridge: Cambridge University Press, 2013), 41. Ekkekasis is drawing here on N.H. Fridja and K.R. Scherer, 'Emotion definitions (psychological perspectives)' in The Oxford Handbook to Emotion and the Affective Sciences, David Sander and Klaus R. Scherer (eds), (Oxford: Oxford University Press, 2009), 142-44; as well as R. S. Lazarus, Emotion and Adaptation (New York: Oxford University Press, 1991); idem., 'Cognition and motivation in emotion', American Psychologist 46 (1991), 352-67; and G.L. Clore and A. Ortony, 'Appraisal theories: how cognition shapes affect into emotion' in M. Lewis, J.M. HavilandJones, and L. Feldman Barrett (eds), Handbook of Emotions, third edn. (New York: Guildford, 2008), 62842.

${ }^{47}$ As Feldman Barrett and Russell put it, a 'prototypical emotional episode' is 'a complex set of interrelated subevents concerned with a specific object', and such objects can be, in Ekkekasis' words, 'a person, an event, or a thing; past, present, or future; real or imagined.' (J.A. Russell and L. Feldman Barrett, 'Core affect, prototypical emotional episodes, and other things called emotion: dissecting the elephant', Journal of 
that psychologists call 'core affect', emotions are 'intentionally directed' at specific cognitive 'objects, events, or states of affairs'. ${ }^{48}$

In one particularly useful recent philosophical account, drawing on and interpreting the broad consensus on the subject in empirical psychological research, Julien Deonna and Fabrice Teroni describe this intentionality of emotion as meaning that emotions always have some sort of 'cognitive basis' (i.e., some kind of cognitive object directly involved in their elicitation). Echoing a recent overview of the psychological literature on emotion by Panteleimon Ekkekasis, ${ }^{49}$ they assert that 'emotions differ from moods in virtue of being intentionally directed at specific objects.' They continue:

[E]motions can equally well be directed at objects, events, or states of affairs with which the subject is presently in perceptual contact ('Ben is afraid of this lion'), with which she had previously been in perceptual contact ('Mary regrets having met Ben in the jungle'), with which she has never been in such contact ('Louis is disappointed that Napoleon lost the Battle of Waterloo'), also with states of affairs with which perceptual contact is impossible ('Rebecca hopes she will travel to Atlantis') ... [E]motions necessarily rely on other mental states in order to be intentionally directed at something. (4-5)

Importantly, this intentionality in relation to cognitive objects means that there is an irreducibly imaginative element involved in emotion - 'imagination-based expectations about a relevant event ${ }^{50}$ - and this explains why we can be sad in the present about things that we have access to only through memory, and why we can hope for things that are impossible. $^{51}$

If we apply this contemporary understanding of the basic building blocks of emotion to Melanchthon's account of forensic justification, it gives us an excellent way of understanding how it is that a shift in doctrine, even a shift as abstract as a change in God's perceptions of and attitude toward a person on the basis of the reckoning of Christ's merits to them in a perceived divine law court, might in fact have a strong and plausible connection to particular emotional, psychological states. The event of coming to faith can be characterized as an imaginative shift in one's present and/or future relation to a perceived or postulated divine judgment. When the 'doctrine' changes - in the case of forensic

Personality and Social Psychology 76 (1999), 806; and Ekkekasis, The Measurement of Affect, Mood, and Emotion, 41).

${ }^{48}$ Julien A. Deonna and Fabrice Teroni, The Emotions: A Philosophical Introduction (London: Routledge, 2012), 4-5.

${ }^{49}$ Ekkekasis, The Measurement of Affect, Mood, and Emotion, 33-51, esp. 40-43.

${ }^{50}$ Deonna and Teroni, The Emotions, 4-6.

${ }^{51}$ Although this broad, relatively simplified position represents a current psychological and philosophical consensus, a number of specific details continue to be the subject of lively debate among philosophers, for example whether or not the intentionality involved in emotion is best characterized by analogy to perception. See especially, Matthew Ratcliffe, 'William James on emotion and intentionality', International Journal of Philosophical Studies 13/2 (2005), 179-202; Sabine A. Döring, 'Seeing what to do: affective perception and rational motivation', dialectica (2007), 363-94; Jan Slaby, 'Affective intentionality and the feeling body', Phenomenology and the Cognitive Sciences 7/4 (2008), 429-44; and Peter Goldie, 'Getting feelings into emotional experience in the right way', Emotion Review 1/3 (2009), 232-39. 
justification from something like 'God judges sinners like me' to 'in Christ God accepts me fully and will judge me no longer' - this entails a change in the 'cognitive basis' of the emotion of terror. Such a change, if it actually takes place, cannot but result in specific and plausible affective consequences - the muting of feelings of fear and the kindling of feelings of peace, joy, gratitude, and so on. ${ }^{52}$

In this interpretation, Melanchthon's consistent interweaving of descriptions of a doctrinal mechanism - forensic justification - with shifts in affective state, far from entailing an inherent contradiction and a failure to recognize the seeds of a disembodied theological rationalism, becomes psychologically plausible, even sophisticated, and a putative opposition between 'propositionalism', on the one hand, and participation, 'embodiment', and affectivity, on the other, is resolved. In terms of cognitive psychology as well as contemporary philosophy of mind, the idea that a conceptual framework like forensic justification would somehow preclude or prevent affective engagement and participation, that it would be affectively blind and experientially unengaged, is a non-starter - in fact cognitive frameworks like this are an irreducible component of most normal human affective processes.

Consequently, although Milbank is correct that such inner, affective change is viewed by Melanchthon and many of those who followed him as not formally necessary to salvation, he is not correct to think that it therefore will not actually happen or that it will not matter whether or not it does. Indeed, we might say that it is psychologically necessary for some such deep affective response to take place, if real belief in the doctrine in relation to the believer's own life is involved.

In Melanchthon's view of justification, then, we have a highly detailed and psychologically specific example of how it can be that, as Lindbeck puts it, doctrines play a key role in teaching us how to 'feel ... in conformity with a religious tradition. ${ }^{, 53}$ 'Forensic justification' was understood from its first major formulation in Melanchthon's discussion in the Apology of the Augsburg Confession to have a particular kind of 'affective salience'. If, like Milbank and those who have built upon his account, we pay attention primarily to the metaphysics of the doctrine - in this case, its apparent nominalist structure or its dependence on Scotist univocity - and not also to its affective salience, we are making a theological mistake. That is, we will end up not only ignoring how the doctrine was articulated in its historical context, but actually arguing for an empirically and psychologically implausible opposition between 'propositions' and their embodied consequences. In terms of the larger argument of this article, this shows how paying attention to concrete and specific instances of the relationship between doctrines and human experience - i.e., rather than making a broad claim that 'doctrine shapes desires', making a more specific claim like 'fear and joy are thought to be shaped by this particular doctrine in this specific way under these circumstances' - can pay substantial theological dividends.

\footnotetext{
${ }^{52}$ Although it does not affect the argument being made here, it is worth noting that the issue of 'time course', or the precise temporal sequence involved in the connection between intentional appraisal of a cognitive object and the elicitation of feeling states associated with emotion, is complex and at the time of publication remains underexplored in empirical research. See Fridja, 'Emotions, individual differences, and time course', Cognition and Emotion 23/7 (2009), 1448-49.

${ }^{53}$ Lindbeck, The Nature of Doctrine, 35.
} 
Furthermore, as the forensic justification example indicates, one of the key benefits of the approach argued for in this essay is that attending to the affective salience of doctrines gives theologians a useful way of relating up-to-date psychological and social-scientific insights to particular theological questions. Although the theological significance or value of a given doctrine by no means reduce to its affective salience, and without question there are theological doctrines that are less well suited to this sort of analysis than others, nevertheless if we do not attend to affective salience where relevant, we risk (i) ignoring the actual historical process by which doctrines develop and are argued for, which often includes claims about their affective impact, and (ii) making theological anthropological claims that are directly at odds with the best contemporary scientific understanding of how human bodies and brains actually work.

As a final comment, it is worth noting that, in comparison to the critique of forensic justification as an inevitably disembodied nominalistic-univocal propositionalism, the interpretation above makes far better sense of an important fact on the ground in the history of protestantism: namely, that a great deal of affectively charged evangelical and revivalist preaching and practice - unquestionably one of the major 'sites' of widespread and vigorous religious emotional experience in protestant history - has often strongly emphasized forensic and imputation-based soteriological models. This is the case not only for magisterial reformers like Luther, Melanchthon, and Calvin, but also for many later figures, from George Whitefield ${ }^{54}$ to Nicholas Zinzendorf ${ }^{55}$ to Billy Graham. ${ }^{56}$ An interpretation that pays attention to the affective salience of doctrines helps make far better sense of this fact, which critiques of forensic justification via its genealogy from positions within scholastic theology are not easily able to explain.

In this article I have argued that one excellent way to take Lindbeck's project forward into new constructive territory is to take his account of the role of doctrines in the shaping of religious experience and emotion further into the realm of concrete examples, which I have then analyzed in various ways. I have called this attending to the 'affective salience of doctrines', and have shown that this can be done in an historical as well as an empirical mode, by examining specific strategies of doctrinal argument that emphasize their perceived affective consequences. Doing so has a number of advantages. First, it alerts us to ways that doctrinal debate has often been shaped in the history of the church by alertness to the "weave of practice" ${ }^{57}$ that generates it and is generated by it. Second, especially when connected with good cognitive and social science, such an approach can serve as a useful test or check on a certain kinds of more conceptual and 'metaphysical' arguments, especially where such arguments use theological anthropology to draw specific claims about contemporary Christian experience and practice. Third, awareness of the actual or perceived affective salience of doctrines gives us a way of thinking through the ways in which

\footnotetext{
${ }^{54}$ See George Whitefield, 'Sermon 46: Of Justification by Christ' in Lee Gatiss (ed) The Sermons of George Whitefield, vol. 2 (Wheaton, IL: Crossway, 2012), 239-49.

${ }^{55}$ See the conversation between Zinzendorf and Wesley, recorded in Wesley's journals, in which the main point of disagreement between the two was over whether justification is imputed (Zinzendorf) or infused (Wesley). John Wesley, Journals and Diaries II (1738-1743), W. Reginald Ward and Richard P. Heitzenrater (eds), The Works of John Wesley, vol. 19 (Nashville, TN: Abingdon Press, 1990), $211 \mathrm{ff}$.

${ }^{56}$ See Timo Pokki, America's Preacher and His Message: Billy Graham's View of Conversion and Sanctification (Lanham, MD: University Press of America, 1999), 151-53.

${ }^{57}$ Higton, 'Reconstructing The Nature of Doctrine', 10.
} 
theological beliefs are informed by our experiences without either reducing the beliefs to the experiences, as Schleiermacher is often interpreted as doing, or reducing the experiences to the beliefs, as Lindbeck largely does.

It is easy to imagine how to apply this sort of approach to other doctrines, and to foresee interesting new questions that could arise from doing so. For example, one might quite naturally expect that different doctrines of the eucharist would have clear affective salience, and that shifts in these doctrines would have practical, affective consequences for the experience of receiving the eucharist, just as experiences of the eucharist could also cause a person to shift their doctrinal view of what they are experiencing. Likewise, analysis of debates over, for example, supernatural healing will be superficial if they do not take account of the fact that theologies of healing are likely to have different affective salience for those without access to good medical care than they will for, say, young healthy churchgoers in the developed world. And then there are a host of questions that would come up about precisely when and where doctrines are actually communicated and taught, and how context affects such salience - it seems likely, for example, that the same doctrine might have different affective salience when communicated from the pulpit or set in a musical context than it would during a classroom lecture or through reading a piece of academic writing.

It is a theological commonplace that some doctrines - different traditions will disagree on which ones - come to have deeply problematic, even pernicious, affective effects in the lives of particular Christians in particular contexts. Attending explicitly to the affective salience of doctrines will help make contemporary theology wiser on this front than it has been in the past, and better able to foster creative, accurate, and affectively-compelling visions of Christian life in the future. ${ }^{58}$

\footnotetext{
${ }^{58}$ I am especially grateful to Bonnie Poon Zahl and Emily Troscianko for their input on the cognitive science employed in this article.
} 